DOI: $10.24234 /$ wisdom.v17i1.449

Tetiana URYS,

Tetiana KOZAK, Svitlana BARABASH

\title{
NATIONAL IDENTITY: FORMATION AND REALISATION THROUGH POETRY
}

\begin{abstract}
National culture, especially literature, contains invaluable nation-building potential and is an effective factor in influencing the development of the national identity of the individual and the ethnic group as a whole. In the process of forming literary works, the author's consciousness and subconscious play an important role, so they are not only one of the best ways of expressing a creative personality and a form of its reaction to events occurring in the outside world, but also one of the most important means of forming the national identity of the recipients. Therefore, such a literary work contains a modus of national identity. The main content of this concept in the literature is revealed in the article. Its theoretical components and their functional aspects in the text are defined and analysed. The modus of national identity is formulated as a way of realising the identity of one with his nation through certain aesthetic elements and structures at all levels of literary work as an artistic system. Such element-dominants are motives, artistic imagery, lyrical character as the main expression of the author's thoughts, as well as archetypes, symbols and place names.
\end{abstract}

Keywords: the modus of national identity, poetry, motives, archetypes, symbols, place names.

Introduction

A characteristic feature of modern sciences is the increased attention to the problems of national identity. This has been facilitated by the social, cultural, historical, political, economic, and other circumstances of life in a globalised and multicultural world. The deepening interest of scientists from different fields is quite natural and is connected firstly with the understanding of values of the new century, increasing tendencies towards conscious growth of national consciousness, awareness of its necessity as a basic component of state formation. Moreover, a formed, well-established, and strong national identity is a peculiar method of resisting the encroachment of other nations on sovereignty, the forcible seizure of territory by assimilation and the imposition of another identity, etc.

Culture is an integral part of the phenomenon of national identity and one of the tools for building civil society and for the qualitative development of the nation. Art, in particular literature, aims to create, preserve, restore and develop the national-cultural organism of society and thus to influence the formation of its national identity. The artist's connection, his work with the nation and its culture, is immanent and per- 
manent, explicit and implicit at the same time. Any artistic creation comes from ethnic backgrounds, so it has the appropriate character and aesthetic features. Artworks, in the process of formation of which the author's consciousness and subconscious play an important role, are not only one of the best ways of expressing a creative personality and a form of his reaction to events taking place in the outside world, but also one of the most important means of creating a national identity.

The purpose of the research is to conceptualise the concept of "modus of national identity" in fiction, to determine the theoretical constituent-constructive dominants of its aesthetic embodiment and the functional aspects of their implementation in poetic work.

\section{The Analysis of Sources and}

Recent Researches

The question of defining the concept of "identity", as well as the associated ones - "identification" and "self-identification", still remains difficult. Let us turn to the achievements of those sciences that dealt with the study of the outlined phenomenon, in particular, psychology (J. Howard, M. Leary, J. Tangney, E. Erikson, S. Freud, etc.), philosophy (M. Kozlovets', O. Lisovy, F. Medvid, etc.), sociology and anthropology (N. Glebova, M. Gibernau, H. Dyserinck, E. Smith, etc.), that study "identity" as a general category; sociology, ethnology, political science, and cultural studies, etc. (J. Sitrin, O. Shmorgun, A. Hadfield-Amkhan, J. Laszlo, etc.), the subject of interest of which is national identity.

The study of this question in the field of psychology is mainly related to S. Freud and E. Erikson. The first introduced the term into scientific circulation, and the study of the second was crucial in forming the outlook of other researchers on this problem. The term "identification" (from Latin identificare - to identify) is interpreted by psychologists as an emotionalcognitive process of identifying a person with another person, group, model on the basis of emotional connection, incorporating them into their inner world and accepting as their own norms and values, so as a result of which one's own personality is formed and manifested. Therefore, in psychology, it is defined as a mechanism of socialisation, which is appeared in the acceptance by an individual of a certain social role when joining a group, in the awareness of group membership, the formation of social attitudes, etc.

In psychoanalysis, the term "identity" is used to explain the phenomena by which the "super-ego" of the individual is formed. The person assumes a certain social role, which is considered as one of the mechanisms of psychological protection that consists in unconsciously likening itself to another object that causes negative experiences. The author of the theory of the protective mechanisms of personality is Anna Freud. Her research is associated with the emergence of the term in the psychology of personality. Later, they formed the basis for the therapeutic practice of psychoanalysis used by the proponents of $\mathrm{H}$. Hartmann's “ego" psychology, H. Kohut's psychology of self, and K. Horney's Neo-Freudianism. It is from these practices that research has penetrated into the plane of self-development and self-identity of the individual and subsequently into personal (individual) and social (group) identification.

The next stage in the development of the concept of "identity" can be considered a psychosocial concept by E. Erickson, based on the peculiarities of interaction between individual 
biological changes and the sociocultural environment. The author of this concept has divided the self-development of the individual into eight stages, characterised by biological and psychodynamic changes and imposing specific social requirements on the individual. At each stage, the identity of the individual evolves, completion of which means a sense of self-efficacy and psychological well-being.

At the present stage of the development of psychological science, there are different approaches to the study of the phenomenon of identity: psychoanalytic, behavioural, cognitive, existential-humanistic, structural-dynamic. Proponents of the cognitive approach view the concept of "identity" as a cognitive system that has two subsystems: personal and social, and therefore explore their relationships and manifestations of personality. In particular, in a joint study by American psychologists R. Ashmore and L. Jussim Self and Identity: Fundamental Issues (1997), this aspect was one of the defining aspects of the problem. They did not only reveal the peculiarities of the antinomy of the personal and social nature of the concept but also determined that it is a potentially complex phenomenon, one of the conceptual and empirical tools for exploring an even more complex concept "personality" (Ashmore \& Jussim, 1997, pp. 323).

American psychologists M. Leary and J. Tangney, exploring personal identity, explain the term as a capacity for self-reflection and selfawareness. Based on studies of the interaction of self-determination and socialisation of personality, the formation of identity in the context of social interaction, they concluded that the development of identity is still impossible beyond the synthesis of identifications that were formed in the process of socialisation (Leary \& Tangney,
2003, pp. 2-21).

The Belgian comparativist $H$. Dyserinck came to a similar idea. He devoted his exploration to social identity, exploring it through the connection of personality psychology, the structure and function of the social groups to which he belongs. He found that people have a need to be part of a community, and because of that sense of belonging, they feel protected (Dyserinck, 2003).

American sociologists P. Thoits and L. Virshup (1997), exploring this aspect of the problem, have determined that individual identity ("Iidentity") includes role identities and collective identity ("we-identity") contains group and social-categorical identities (pp. 106-133).

Hungarian psychologist J. Laszlo in his work Historical Tales and National Identity: An Introduction to Narrative Social Psychology (2014), also considered this concept in a social context. He observed that in the humanities, personal identity is contrasted with social identity. The author draws a distinction between personal and social identities from the concept of the psychologist W. James, according to which the personality consists of "I" (subjective component) and "me" (objective component having a social origin). In other words, each personality has a certain set of roles that he performs in society. Therefore, the nature of the process of personal identification is determined by the society in which the development of the individual takes place (Laszlo, 2014, p. 200).

While the issue of personal identity is about individual identification and is related to the ego of the individual, the concept of social identity is related to the phenomena that arise through the collective way of life, which in turn determines assimilation of the values and goals of the group by the member whom he considers himself. The 
theories of social identity by British psychologist H. Tajfel and the self-categorisation of American sociologist J. Turner (1979) explain the group behaviour of people (pp. 33-47).

Social identity is the result of social comparison, in which people seek to perceive their own group in order to be different themselves not only from other groups but also to be better than them. Identity is not a negative phenomenon because the social categorisation (according to $\mathrm{J}$. Turner) that underlies it does not in itself mean discrimination but is an easy way to attach a certain meaning to a person in the social world. Thus, the identity of a person or a collective (as a whole organism) is determined on the basis of difference from others. The presence of two common types of identity in the individual - social and personal - is confirmed by sociologist J. Howard in her study Social Psychology of Identities (2000). Social, in her opinion, is determined by membership in different social groups and personal - by idiosyncratic properties that distinguish one person from another (Howard, 2000, pp. 367-393).

Thus, the term "identification" is defined as the emotional-cognitive process of identifying an individual with another subject, group, or pattern that develops non-linearly throughout one's life. The result of this process is the identity that a person acquires in the process of his individual development; a dynamic system that has a complex hierarchical structure and is determined by the person's desire for integrity, belonging to a particular group (social, ethnic, etc.), a sense of owning himself (at the level of cognitive, emotional-evaluative and behavioural components) in society.

Identity determines the peculiarities of selfperception and self-control, attitude towards other people and behaviour of the individual. The process of its formation goes through a number of phases of development from childhood to the end of life, filling with a certain sense of personality's "I". Identification as a psychological process is very important in the behaviour and mental life of the individual because it provides an expansion of the range of experiences, enriches the internal experience, allows overcoming fears, feelings of weakness and inferiority.

Identity is a human need and justified by the necessary processes of socialisation, self-realisation, self-development and self-improvement. The process of formation and revealing identification by a creative personality distinguishes among others by the special depth of perception, emotionally, high vitality, non-standard thinking and so on. For example, poets who interpret reality model the feelings of their lyrical hero, investing in him the specifics of their own essence, their identity.

One of the varieties of identity personality that is considered the most debatable and problematic in society today is national identity. In understanding the meaning of this term, the important role plays the concept of "nation" as one of the most important reference groups; the natural social community of people, which has its name, territory, language, origin (generic community), a cultural information field with codes and symbols that can distinguish the members of this nation. For its inner unity, the culture is essential. It gives people an awareness of their community (oneness). The originality of national culture is manifested through traditions, customs, rituals, folklore and language that preserve the specificity of national spirituality for transmission to the next generations.

A significant national identity researcher E. Smith (1991) defined it as "a continuous reproduction and new explanation of the characteristic 
people, symbols, memory, myths and traditions which form the personal heritage of the nation, as well as identifying individuals with these traits and constituents of culture" (pp. 23-24). In addition, he differentiated each personality's "I" into different identities and roles - family, territorial, class, religious, ethnic, etc. The scientist identified national identity as a key cultural identity and identified its main features: historical territory (native land), common myths (historical memory), common culture, economy, legal rights and obligations for all members of the community.

National identity, in fact, is an associative attribute that not only helps to identify the specificity and direction of cultural development, politics, and other spheres of a nation's life but ultimately to protect them.

National identification, like any other human process, has a philosophical and psychological basis. The philosophical basis is determined by the outlook, place of birth, religion, the culture of the person, the choice of life landmarks, the correlation of social and personal values; psychological basis - by the internal psychological processes, the peculiarities of reactions to external events as stimuli, psychological characteristics, temperament, person's character, etc.

National identity is the result of the process of consciously-subconsciously identifying one's personality with one's own nation, of the process of self-affirmation personality as a carrier of a corresponding culture, of realising own involvement in the system of one's values (language, ethics, cultural heritage, etc.).

The common culture, history, love of the land, myths and symbols that can generate emotional connections are, from the point of view of Catalan researcher M. Guibernau (2007), the "core" of national identity, its main components.
Ukrainian sociologist N. Glebova has come to a reasonable conclusion that national identity is correlated with both objective and subjective reality. Among the objective identities, she calls to the place of birth and residence, geographical area, social group, ethnic group, national community, language, traditions, customs, rituals. Identifying people with them or actually belonging to them leads to being interpreted as "their own" (Glebova, 2012, pp. 119-122).

J. Laszlo emphasises that the formation of national identity takes place in at least three channels: historiography, collective memory, art (particularly literature). At the same time a representative of narrative social psychology notes that certain patterns and characteristics of identity are mediated by folklore historical narratives (Laszlo, 2014). Therefore, there is no doubt about the connection between the psychosocial concept of "national identity" and fiction. E. Smith also emphasised this in his time. He believed that literature is an important source of becoming and formation of national identity since it accumulates the depth of human consciousness, historical memory, mentality, the national character of the people, etc. The creativity of any artist is in one way or another an expression of his worldview, his philosophy of life, and therefore a reflection of his identity, including national (Smith, 1991). Therefore, the existence of a modus of national identity in literary works is reasonably well-founded. The purpose of such literature is to form the national consciousness of society, to influence its development, to promote its consolidation.

\section{National Identity in Poetry}

The concept of "modus national identity" in an artwork is explained as a way of identifying a 
person with his or her nation through certain literary elements and structures at all levels of literary work as an artistic system. It is based on the national type of thinking of the author, who is the bearer of the national spirit and the implementer of the national idea.

Today, many scientists around the world are exploring issues of national identity in the literature of representatives of different nationalities. For instance, Khalil Hasa Nofal from Philadelphia University researched how the concept of national identity is portrayed in Mahmoud Darwish's (1942-2008) poetry, one of the most prominent Palestinian poets. He explored the identity through different things: language, homeland, roots and ancestors, belonging, nature, culture, traditions etc. K. Nofal focused attention on those themes in Darwish's poetry that connected with the concept of homeland illustrated by references or images of mother, geography, history, and folklore heritage. Nofal (2017) also explored the expression of the concept of national identity in poetry by an Irish writer William Butler Yeats (1865-1939) (pp. 67-77). Alice E. Popowich (2013) investigates the role Ausiàs March's (1397-1459) oeuvre played in the creation of the distinct national identity of nineteenth-century Catalonia.

Many scholars have also investigated this issue in Ukrainian literary studies. In particular, S. Adrusiv (2000) explored the modus of nationnal identity in the works of Western Ukrainian writers, and L. Senyk (2002) - on the example of Ukrainian novels of the 1920s, and Yu. Marynenko (2004) - in Ukrainian prose of the 40s-50s of the $20^{\text {th }}$ century. M. Ivanyshyn (2015) tried to outline the peculiarities of the development of national interpretation in postcolonial literary criticism and the productivity of its application in the Ukrainian historical-literary works of modern scholars.

The modus of national identity is expressed in textually both semantic and formal levels of literary work. The writer discovers his own ideas in the context of his nationality, embodying thoughts in national motives, images rooted in tradition, folk poetical symbols and archetypes through symbolic structures of mentality. These dominants transpose national traditions, customs, rituals, features of the national character, peculiarities of national consciousness and mentality. They reveal the modus of national identity in a literary work.

At the semantic level, it manifests itself in the motives through which the author conveys his thoughts and feelings. The realisation of any motive depends on the emotional "I" of the author, who is his lyrical hero. Therefore, one of the characteristic determinants of the modus of national identity in poetry is the lyrical hero, who identifies himself with his nation and represents the specialities of the national existence of the author.

At the structural (formal) level, the modus of national identity is expressed through the presence of national images, symbols, archetypes, place names. Among the formal features are worth noting the immersion of this modus in ethnic memory, mythology, ceremonial acts, the presence of poetry in the folklore, symbolic subtext and archetypal content. In poetic language, aesthetic meaning and artistic ideas are revealed primarily through the images. National images are peculiar markers that, at the poetic level, adopt the concept of "national identity" and appeal to the national identity of the author and the reader. These images are their cultural manifestation. 
Many poets are characterised by the formation of imagery on the basis of national-outlook need. The key concept here is the country with which the author associates, and the attributes corresponding to it, are the dominant figurative complex of the lyrics. Together, they form a holistic picture of being a people with whom the author identifies himself. The functioning of national-centric images in poetry testifies to their presence in the minds of poets and, therefore, to the well-formed authors' national identity.

Poetry that contains a modus of national identity also has a distinct multi-associative subtext due to place names, personalities, various features of a particular ethnic group. The folklore and ethnographic foundations of the imagery of these literary works should be emphasised. Appeal to folk sources, in particular to folklore, is quite logical because it hides the centuries-old experience of being a people.

The lyrical hero is not only the subject of the statement in the poetic text but also the carrier, a form of artistic presentation of the author's consciousness, which fully reveals the poet's outlook. The peculiarities of his implementtation in the poetic text, his character, temperament, attitude to the outside world, etc., make it possible to reveal the poet's artistic world.

National identity and the author's consciousness have a well-founded connection psychologically. Since this identity is part of the concept of the author's personality, it is fair to speak about the peculiarities of its formation in the lyrical hero and his national determination, and therefore the textualisation of his national identification.

The lyrical hero plays an important role in the system of dominants of the modus of national identity. He is a direct form of expression of the author's consciousness because he is characte- rised by the concentration of the poet's thoughts on a certain range of problems.

The lyrical hero is a peculiar alter ego of the author, which is why he embodies his ideas the best. And, therefore, the poet's national determination, and in accordance with the national selfidentification, is conveyed to him.

Such a hero is in the works of the modern Ukrainian poet from Volyn I. Pavlyuk, the author of the poetry collections "Islands of Youth" (1990), “Glass Tavern” (1995), “Allergy to Eternity" (1999), "Revolt of Holy Water" (2005), "Magma” (2005), "Rebellion” (2006), "Ukraine in Smoke" (2009), and others. He is nation-centric by nature: he identifies himself with the Ukrainian nation, his native land, the place where he was born. As a native of the village, his lyrical hero is characterized by a strong connection with the land and nature. He openly expresses his civic position, identifying himself with his native land: with his "small" homeland - Volyn and "big" - Ukraine. Like the author, the lyrical hero is deeply rooted in his land, the land where he was born:

I've been through the ages hundreds of times -

And hundreds of times, this land is dear to me

(Pavlyuk, 2006, p. 23).

The modus of national identity in the literary work on the semantic level is expressed primarily in the motives, through which the author conveys thoughts and emotions. They are respectively realised through a series of macro- and micro images, images-symbols, archetypes, place names (toponyms), etc., and characterised by ethnonational specificity. The historical events of a country certainly influence the formation of national images in its literature. They construct the national identity of the depicted characters, landscapes or historical past, presenting some of their characteristics as typical for the 
concerned country and characteristic for the whole its people. Modern imagology notes the close relationship between the national identity and the national image: national identity influences the formation of national images, and they, in turn, construct it.

Poets artfully model many eternal and more contemporary topics relevant to society, such as love, betrayal, immorality, spiritual degradation, space, God, philosophy, etc. The motives and images of their creativity are diverse, but they enter into poetic contexts that rely on a deep national basis, in particular on folklore, the creativity of the classics of national literature. These artists present with their lyrics a national identity that reflects all the changes that are happening with the nation.

In the artistic space of poetic texts with a modus of national identity, we find motives rooted in our homeland, deep love for the "small" and "big" Motherland, devotion and sacrifice, motives of freedom, preservation of the national spirit and at the same time ideas, rebellion and struggle, kind and childhood, artist and art, continuity of traditions, as well as the motives for the loss of national values, the lack of spirituality and feeling rooting of society as a nation, alienation, non-belonging to the people of their land, spiritual occupation of the Motherland, the development of the country in the conditions of the latest denationalisation, spiritual and physical death of the people in conditions of the not-freedom, denial of the complex of national inferiority, minorities and marginality, passivity of the people and many others.

The motives of poetry containing the modus national identity are realised through nationally rooted images, such as the steppe, land, forests, mountains and their marked equivalents. The predominance of one or the other depends on the geographical topos of the people's existence that influenced the formation of their mentality, character and, ultimately, identity. The images that emerge from the poetry of I. Pavlyuk, P. Volvach, I. Andrusyak and other Ukrainian contemporaries - the family, topos of land, steppe, national historical and cultural figures, etc. - also testify to the existence of the author's national self-determination and its implementation in the lyrics.

\section{Archetype as One of the Striking Markers of the Modus of National Identity}

The creativity of the writer is ambivalent for its nature. On the one hand, it is completely individualised and, on the other, full of archetypal patterns. In the process of creativity, the human psyche returns to the subconscious, to the encoded information that is revealed in the literature mainly through archetypes. They are one of the determining national identification factors in poetic texts.

Archetypes are prototypes (primordial images) or ideas that emerge on the "surface" of consciousness while reading a text, actualising the universal characteristics inherent in the national mentality and human race. The concept has become widespread in literary theory and criticism through work in the field of psychoanalysis by Swiss researcher C. G. Jung. He explained the nature (form) of the archetype through its resemblance to a crystal whose axial structure determines the structure of its formation but not its material expression. Carl Jung (2005) wrote that the archetype itself is empty, purely formal, and is only a possibility of imagination, the ability to discover what is given a priori (p. 214). In other words, the archetype is a model that is implemented in different ways but has no specific 
meaning, an image that acquires specific meaning only through conscious experience.

In psychology, the archetype is seen as a collective unconscious, in cultural studies - as a basic element of culture, forming the moral imperatives of the spiritual life, and in literary criticism - as a concept in which basic, universal for all humanity, images, topics, plots are realised in the text through archetypal images. The archetype contains a priori knowledge. Its main feature is the ability to constantly reproduce. It is a representation of the collective unconscious, historical memory of humanity. The archetype does not function within only the same text or one author's texts, which is why they are considered universal concepts (structures). But the archetype is also a subconscious manifestation of ethnogenetic memory and is closely linked to such concepts as national character, mentality, heredity, continuity. In addition, it certainly plays an important role in preserving the spirituality of the nation. Each national culture has its own specific content (that is, a set of archetypal images) of such a universal structure. In each culture, archetypes are enriched by their own national specificity, expressive features of the nation's mentality. They have layers of ethnic traits, cultures of a particular people. The ethnonational archetypes are passed down from generation to generation as a genetic memory of the people and the experience of previous generations. Literature has a direct connection with them through folklore, myths, ethnography.

One of the main functions of using archetypes in work is to return to historical memory, to the sources of national consciousness of the people, to connect the past, present and future. Archetypes demonstrate the unique psychological personality of the nation, which is related to the peculiarities of outlook, the nature of artistic creativity, and the historical fate of the people.

In the lyric, which contains a modus of national identity, we consider the presence of ethnocultural archetypes as one of the artistic categories of poetic text, which is manifested in a number of national images. In addition, the same images in different contexts may explain differrent archetypes. Constant archetypes that implement the modus of national identity in the poetic text are considered the Archetype of the Genus, the Archetype of the World Tree, the Archetype of the House, the Archetype of the Mother, and the Archetype of the Word.

The Archetype of Genus is associated with the cult of ancestors, so its figurative and symbolic structure is manifested in homage to deceased relatives. It represents the union of dead ancestors, living descendants, and the future, unborn generation. This archetype is associated with the glorification and the exaltation of the genus. The main images that reproduce this archetype are relatives and family, that is, images of a mother or a grandmother (as the keepers of ancestry), grandfather, and older ancestors. The deep rootedness of the Archetype of Genus in the author's subconscious is found in Pavlyuk's works, in particular in the poems "In our house", "On the wormwood infused fog", "Such deep blood", where it is realized through warm and bright images of family elders, oven and utensils of the house.

The Archetype of the World Tree is a unique model of the universe where each creature, object, or phenomenon has its place, thus embodying the universal concept of the world. In poetry, it's objectified in different archetypal images depending on the mythologies of different nations, including the tree of life, the tree of the genus, etc. In every specific national literature, this image is different, for example, égig érő 
fa in Hungarian mythology, the oak in Slavic, Yggdrasil in Norse mythology, the Tree of the knowledge of good and evil in Judeo-Christian mythology, the olive tree, named Moriai, in Greek mythology and so on.

The Archetype of Home is embodied not only in the house but also in the native land, "small" and "big" Motherland, in the image of one's hometown or village, native street or quarter, the area where sweet and bitter memories, happy and sad events are related with childhood and adulthood. This archetype is the epitome of the spatial world, the centre of every person's emotional life. The parental home's topos is its materialised embodiment. Moreover, this image can both embody shelter, protection from the terrible world, harmony and manifest through images of a wasteland and a destroyed house, symbolising the destruction of harmony of national space. In Ukrainian poet P. Volvach, the image of the native land as the Archetype of the Home is concretized through the steppe region of Ukraine - the South-East and Zaporizhia. His lyrics depict the boundless steppe space, which symbolizes freedom, independence and defiance. This place endowed his lyrical subject with the traits of invincibility and rebellious spirit of a Ukrainian Cossack. His city is industrial, smoky, smoky and completely Russified, with a marginalized society, but it is his home, and it is rooted in this city. He believes in "the special purpose of this land", because here "passionate blood infused with wormwood", "Azov-Black Sea waves", "planetary mystery of the Steppe", "muffled blunt hooves", "iron-coal power" (Volvach, 2002, p. 5).

The Archetype of the Mother manifests itself in images that are connected with the idea of fertility and embodied in the macro-images of mother-earth, mother-nature, and ultimately the mother-woman. Earth is considered the mother of all things and is portrayed through the image of the "big" and "small" Motherland, represented by micro-images, which form a peculiar microcosm of the poet - his native village or city, his parents' house, forest, steppe, mountains, marked by distinct ethnogenetic feature. Nature paintings are sometimes depicted through psychologically filled synesthesia micro-images, familiar to the writer's heart landscapes. Most often, it is alive, anthropomorphised, empowered to move, think, and feel.

The Archetype of the Word in poetry is revealed through the images of the artist and his creation. Poets have always pondered the purpose of creativity, their place in society. The actual questions remain: "What and for whom should a poet write?" After all, the WORD is a powerful weapon: it calls for a fight, raises the national spirit, opens the truth, saves in a variety of situations. This archetype is also represented in poetry by images of prominent figures of this nation who, in their own words, supported the development of national culture. They are the bearers of the code of national memory, and therefore help to shape the national consciousness of future generations, which, in turn, preserves the belief in self-insights, self-awareness, and ultimately the prosperity of the people.

Archetypes express the author's national identity at the structural level of the art text. Although they are universal units, they have a clear national specificity and appropriate content. The subconscious manifestation of ethnogenetic memory, expression of ethnic features, and their saturation with traits of national character occur through them. 
Traditional and Individually-Authorial

Images-Symbols as Elements of Expression

of National Originality in Creativity

Symbols are a kind of figurative and psychological formations that function as certain mental codes that accumulate the historical experience of a people, contributing to its preservation for future generations. They are the bearers of the cultural, historical, psychological, and aesthetic heritage of the nation. In literary studies, a symbol is considered a specific type of artistic image that goes beyond its own borders, makes some sense, closely fused with the image, but not identical, pointing to some fundamentally different object.

This specific literary category is characterised by ambiguity (impossibility of unambiguous interpretation), emotionality, suggestibility, multilevel, multiplicity, and inexhaustibility of meanings. An image-symbol in a work of art performs several functions at the same time: informational, emotional-expressive, axiological (evaluative), etc. An image-symbol in a work of art performs several functions at the same time: informational, emotional-expressive, axiological (evaluative), etc. It contains a secret internal link to what it indicates.

Symbolism - both traditional and individual-authorial - is an important factor in creating a national-cultural picture of the world in the text: traditional - because of its folklore basis, individual-authorial - through the reproduction of nationally predetermined features of the author's thinking.

Symbols have a generalised meaning (intertextuality), but on every other national ground, they have intermediate meanings and develop new figurative associations. Each nation has its own specific national system of cultural symbols, which is connected with the peculiarities of thinking and consciousness (understanding), language, and culture of this nation. National tradetions, customs, rituals, beliefs, common traits, artists' level of national consciousness are often reflected precisely in the symbols. Symbols, both traditional and individual, are not only an important fragment of the aesthetic picture of the writer's world but also those concepts that reflect the modus of national identity in poetic works. Among these symbols can be distinguished some of their groups: religious (images-symbols of the crucifixion, Jesus Christ, God, paradise and hell, icons), pagan (images of Perun, Kurgan stelae), floral (viburnum, cornflower, featherweed, wormwood, mallow), bestiaries (horse, stork, crane), symbols for designation of objects (candle, sabre), etc.

Echoes of pagan culture seem to pass through the soul of the lyrical hero by I. Pavlyuk. Here next to him are mythological and demonological characters - mermaids, monkeys, witches, and others ("Witches", "Scythian", "Mavka", "River", "That's how my life will pass", "Again about the witch", etc.). I. Pavlyuk introduces human into the coordinate system of the natural world, reveals its essence as a part of nature. The reason for this is the author's inherent pantheistic understanding of the world, the roots of which in his native Volhynia, where human has long merged with nature, formed a single whole with it. Among the pagan symbols dominant in his works are the images of a stone woman who can "carry the crosses of space work" (Pavlyuk, 1994, p. 29) or to act as the foundation of a meadow that "stretches a hand to someone" (Pavlyuk, 1994, p. 62).

Symbolism as a form of expression of the author's intention is also considered literaryaesthetic dominant of the textual expression of 
the modus of national identity in a poetic work. The essence of the national spirit and the national specificity of literature are expressed in symbolism. National symbolism embodies the system of ideas, opinions, and beliefs that the ethnos has produced over the centuries; they form the ideological basis of its life, culture, spirituality. The system of such images creates a kind of nationalsymbolic metadiscourse. National symbolism as a sign system aims at expressing and shaping the national identity of the people, their worldview, and their own picture of the world.

\section{Geographic Nominative of National Space in Poetry}

The writer's worldview is formed due to many factors, among which the dominant place is taken by the environment, in particular the region (small homeland) where he grew up, learned to perceive the world, realised himself as a person. In the consciousness and the subconscious, the territory is formed through certain images and is reflected through toponyms, which are peculiar documentary facts in the canvas of an artwork, where they mark the national specificity of these poetic texts.

Artistic onomastics is an important source of information in comprehending the textual and subtextual content of a literary work, one of those lexico-stylistic elements of the structuralsemantic organisation of the text, which, specifying the general figurative content, creates a special space in work and forms a complete picture for recipients. Considering the frequency, nature, and functional load of the poetonyms used by the author can determine his outlook, aesthetic taste, the circle of his connections, influences, or inclinations. A special group in this context is place names (toponyms). They ac- cumulate significant extralinguistic information: point to a time or event, act as symbols of historical events, categories of space and temporality, and so on. Because of their emotionally rich connotations, they are another manifestation of the writer's national identity.

The set of place names forms a certain toponym space in the author's poetic system of speech. It is unique to every writer, which defines for the reader another important detail in the author's biography - his geographical space. The toponymy of nationally-identified writers is largely structured by the names of the local area of their origin and is aimed at forming a holistic image of their country. Such territorial attachment to the terrain is formed by the characteristic toponymy (hydronyms, oykonyms, oronyms, horonyms, etc.).

Place names, first of all, perform a spatial function in a literary work (localisation of objects and actions). Due to them, the territory, natural and geographical conditions of formation and existence of the nation are delineated. They give realism to the image of reality, convey local features, create visual images of a particular area.

These geographical nominatives also carry implicit information and act as a symbol. Such a symbolic representation of the ideological content of a literary work means that all place-names are certain symbols, and therefore they conceal the hidden meaning and purpose that the recipient must decipher. In addition, every real placename used by the writer is a kind of linguo-cultureme (or ethnocultural concept), which nominates an important cultural meaning and is used in the text canvas to create a unique national-cultural atmosphere.

Toponyms also perform a characteristic function. That is, in the text of a literary work, they are used as auxiliary elements of character- 
creative modelling image of the lyrical hero, his experiences. They concretise the imaginative representation, enhance the impression, create the integrity of the artistic image. Toponyms also perform information-historical and nominativeidentification functions when they act as a chronotope with reference to a particular historical epoch or event.

Another function of place names is sociodeictic, the peculiarity of which is that the events that happened at a certain time in a certain place, the author passes through his consciousness, and therefore we perceive the social phenomena described in the poetic text, through his vision and appreciation. Horonyms - the names of countries and regions - have the highest frequency of use and special importance in the writer's literary works. They form the core of the native land image, and through them, the lyrical texts emphasise the connection with the territory in which their aesthetic consciousness and worldview was formed.

Poetic place names often outgrow the boundaries of connotative localisation, saturated with new meanings, symbolised and become an important means of the emotionally-shaped unfolding of the artistic structure of a poetic work. Such toponyms preserve the semantics that has been shaped by history-related changes in the country's past. They have artistic-aesthetic significance in poetry. Toponyms are also used in the locally topographic function to give the depicted realistic accuracy.

Place names in a particular context, localising an action or object in space, concretise the imaginative representation of the recipients, create visual images of a particular terrain, enhance the impression, give a realistic accuracy to depicted, convey the local features and the desired emotionality. Toponyms are an important linguistic-stylistic element of poetry, as they are often associated not only with a sense of love for a small homeland but also with the national identity of the author's lyrical "I".

Writers' poetic creativity is saturated with geographical and topographic names of their countries. Hydronyms, oykonyms, oronyms, horonyms and other toponyms are peculiar national codes that, through the texts, reflect the writers' national identity. The self-identification of these writers, as well as of their lyric characters, is undoubtedly linked to the local topos and is primarily due to the awareness of themselves as part of the people and the unity of their own destiny with that of their native land.

\section{Conclusion}

Considering the theories of different scholars, we define the term "identity" as a dynamic system that develops nonlinearly throughout human life, acquired during its individual development, has a complex hierarchical structure and is determined by the desire of the individual for integrity, belonging to a particular group (social, national, professional, etc.), the sense of owning one's self "I". National identity is the result of the emotional-cognitive process of consciously-subconsciously identifying one's personality with own nation, the process of self-affirmation of one's personality as the bearer of own culture, the realisation of one's own involvement in the values system.

National identity means the individual's self-determination and self-orientation in the world through the prism of the original culture of his nation, is part of the process of forming the individual's self-determination in society, connected with the formation of social relations of the individual in the structure of the nation with 
which he identifies herself. In this way, the process of formation of cultural, moral, and value orientations, ideals, and norms of behaviour inherent in the mentality of this nation, certain qualitative and quantitative changes in the identity of the individual, occurs in the development of personality. That is, a peculiar process of selfaffirmation of the individual as a carrier of the respective culture is carried out.

National identity is important for the political, social, and cultural spheres of a nation's life since its level of formation determines the overall state of development of society. National culture and art show invaluable nation-building potential. Literature, which contains energy power, plays a significant role in the becoming of national consciousness and the formation of the identity of the nation. National culture and art show invaluable nation-building potential. Literature, which contains energy power, plays a significant role in the becoming of national consciousness and the formation of the identity of the nation. Concentrating on the most significant aspects of national life, conducting an in-depth and systematic artistic understanding of the situation of both the past and the present, and in some places predicting the future, the art of the word preserves national spirituality, affirms questions of national identity, identification, awareness of the cultural, historical, moral and aesthetic-ethical value of the property of society.

Based on the generalisations of literary studies by S. Andrusiv, O. Veretyuk, M. Ivanyshyn, P. Ivanyshyn, L. Senyk, K. Nofal, Alice E. Popowich and many others concerning national identity in literary studies, the concept of "modus national identity" was defined in literary work as a way of identifying personality with his nation through certain literary elements and structures at all levels of the literary work as an artistic sys- tem. The modus of national identity is realised in lyricism due to the specificity of the sensations of the lyrical hero, which are formed within motifs and images through archetypes, symbols, the topos of the "small" homeland, and the "big" homeland, folk reminiscences, etc. It is expressed both textually at the content (motives, ideas, problems) and formal (images, archetypes, symbols, place names, etc.) levels of the text. The lyrical hero has a particular place in this system. For the most part, he is the bearer of the author's worldview and feelings and therefore acts as the main representative of his national identity in the text.

Poetry that contains a national-centric core is a carrier of the modus of national identity, which manifests itself through a system of connected dominants, in particular, the subject sphere represented in poetry by the lyric hero. This category in literary criticism is characterised by a concentration of consciousness, a kind of the author's alter ego. National identity is part of the concept of the author's personality, and his expression in the text is primarily a lyrical hero.

Another dominant in the system of expression of the modus in a poetic work is motive. It is a component that implements the author's ideas and conceptions. Certain motives in the writer's work testify to the identity of the author in more ways than his biographical data and activity since they capture precisely those aspects of social life that bother him very much. Among the motives that embrace the modus of national identity are motives of genus, childhood, the role of artist and art in society, depictions of nationalhistorical realities, national-patriotic, depictions of realities of life of modern society, which are revealed through social, political, historical-cultural, spiritual-moral aspects, etc.

Motives, in turn, are realised through a se- 
ries of macro- and micro-images, images-symbols, archetypes, place names united by ethnonational specificity. The archetype, as a representative of the collective subconscious and displaying ethnogenetic memory, is one of the determining national identification factors. It is closely related to such constructive concepts as national character, mentality, heredity, and so on. Other expressions of modus in the poetic text are symbols that retain in their connotations the historical experience of the people, the cultural-aesthetic values of the nation, its psychological and mental features. The lyrics include both traditional and individual characters. They reflect the national specificity and emphasise the nationalcultural basis of the poets' artistic thinking.

An equally important dominant factor in the expression of the modus of national identity is the geographical nominative of space, that is, toponymic names, which are categories of spatiality and temporality that accumulate mostly extra-linguistic (subtextual) information. The writers' self-identification, as well as their lyrical characters, is associated with those territories that denote the toponyms named in the texts, in this way, expressing their own position about the nation and their native land - the "small" and "big" Motherland.

\section{References}

Adrusiv, St. (2000). Modus natsionalnoi identychnosti: Lvivskyi tekst 30-kh rokiv XX st. (Modus of National Identity: Lviv Text of the 1930s, in Ukrainian). Ternopil: Jura.

Ashmore, R., \& Jussim, L. J. (1997). Self and Identity: Fundamental Issues. USA: Oxford University Press.

Dyserinck, H. (2003). Imagology and the Prob- lem of Ethnic Identity. Intercultural Studies, 1. Retrieved September 11, 2019 from: http://www.interculturalstudies.org/ICS1/Dyserinck.shtml.

Glebova, N. (2012). Sotsialna, natsionalna, etnichna identychnist: vitchyznianyi dosvid (Social, National, Ethnic Identity: The Ukrainian Experience, in Ukrainian). Scientific Papers Peter Mohyla Black Sea State University. Series: Sociology, 189, 119-122. Retrieved October 25, 2019 from: http://nbuv.gov.ua/UJRN/Npchdusoc $2012 \quad 201 \quad 18925$.

Guibernau, M. (2007). The Identity of Nations. Cambridge: Polity Press.

Howard, J. A. (2000). Social Psychology of Identities. Annual Review of Sociology, 26, 367-393. https://doi.org/10.1146/annurev.soc.26.1.367.

Ivanyshyn, M. (2015). Dyskurs natsionalnoi identychnosti $v$ ukrainskomu postkolonialnomu literaturoznavstvi. Monohrafiia (Discourse on National Identity in Ukrainian Post-Colonial Literary Studies, in Ukrainian). Drohobych: Posvit.

Jung, C. (2005). Soul and Myth. Six Archetypes. (A. Spektor, Trans.). Moscow: AST.

Laszlo, J. (2014). Historical Tales and National Identity: An Introduction to Narrative Social Psychology. London and New York: Routledge/Taylor \& Francis Group.

Leary, M., \& Tangney, J. P. (2003). Handbook of Self and Identity. New York: Guilford Press.

Marynenko, Yu. (2004). Misiia: problemy natsionalnoi identychnosti $v$ ukrainskii prozi 40-50-kh rokiv XX st. (Mission: Problems of National Identity in Ukrainian Prose of the 40-50s of the XX 
Century, in Ukrainian). Kirovograd: Imex-LTD.

Nofal, Kh. H. (2017). National Identity in Mahmoud Darwish's Poetry. English Language and Literature Studies, 7(3), 67-

77. http://doi.org/10.5539/ells.v7n3p66.

Pavlyuk, I. (1994) Holos dennoho Misiatsia: Liryka (Voice of the Day Moon: Lyrics, in Ukrainian). Kiyv: Ukrainskyi pysmennyk.

Pavlyuk, I. (2006). Bunt: Liryka i dramatychni poemy (Rebellion: Lyrics and Dramatic Poems, in Ukrainian). Lutsk: Volynska oblasna drukarnia.

Popowich, A. E. (2013). March's Poetry and National Identity in Nineteenth-Century Catalonia. CLCWeb: Comparative Literature and Culture, 15(6). doi: 10.7771/1481-4374.2362.

Senyk, L. (2002). Roman oporu. Ukrainskyi roman 20-kh rokiv: problema natsionalnoi identychnosti (A Novel of Resis- tance. The Ukrainian Novel of the 1920s: The Problem of National Identity, in Ukrainian). Lviv: Academic Express.

Smith, A. (1991). National Identity. University of Nevada Press.

Tajfel, H., \& Turner, J. (1979). An Integrative Theory of Intergroup Conflict. In W. G. Austin \& St. Worchel (Eds.), The Social Psychology of Intergroup Relations (pp. 33-47). Monterey, CA: Brooks/ Cole.

Thoits, P. A., \& Virshup, L. K. (1997). Me's and We's: Forms and Functions of Social Identities. In R. D. Ashmore \& L. J. Jussim (Eds.), Rutgers Series on Self and Social Identity, Vol. 1. Self and Identity: Fundamental Issues (pp. 106133). Oxford University Press.

Volvach, P. (2002). Pivdennyi Skhid. Poezii (Southeast. Poetry, in Ukrainian). Lviv: Calvary. 